\title{
Use of new resistance markers to predict virologic response to antiretrovirals
}

\author{
Mark A Wainberg ${ }^{*}$, Thomas Toni, Bluma G Brenner \\ From $16^{\text {th }}$ International Symposium on HIV and Emerging Infectious Diseases \\ Marseille, France. 24-26 March 2010
}

\begin{abstract}
Aim
There can now be little doubt that certain drug-resistance mutations are more likely to emerge in viruses of certain subtypes than others. Two of the best and most practical examples of this are the emergence of the V106M NNRTI mutation and the K65R NRTI mutation in viruses of subtype $C$.
\end{abstract}

\section{Methods}

It is relevant that the use of newer more sensitive methods have been key in establishing the role that certain drug-resistance mutations may play in both transmitted and acquired drug resistance. In particular, the use of allele-specific PCR assays (AS-PCR) and pyrosequencing have been very useful in providing new insights.

\section{Results}

Among the reasons that more ultrasensitive assays may sometimes be needed for more accurate assessments of drug resistance is the differential effect of certain mutations on viral replicative capacity. As an example, the K65R mutation is known to adversely affect HIV replication, and this may be one of the reasons that it is found relatively infrequently among individuals who fail antiretroviral therapy. In contrast, the use of AS-PCR for $\mathrm{K} 65 \mathrm{R}$ in subtype $\mathrm{C}$ viruses has shown that this method was able to detect the presence of this mutation in an additional 4 of 30 samples who had tested negative by bulk sequencing methods. Now, it also appears as though the transmission of the K65R mutation, while rare, can also be detected in higher numbers by AS-PCR than bulk sequencing, and that this is also more common among subtype $C$ than subtype $B$ viruses. The likely reason is that subtype $C$ viruses are more prone to develop $\mathrm{K} 65 \mathrm{R}$ as a consequence of treatment failure

\footnotetext{
McGill University AIDS Centre, Jewish General Hospital, Montreal, Quebec,
} Canada H3T 1E2 and are therefore more likely than subtype B viruses to contain this mutation at the time that transmission takes place. In the case of the M184V mutation, it has also been observed that AS-PCR methods can detect this substitution more efficiently than bulk sequencing among newly-infected individuals.

\section{Discussion}

Thus, the reason that some resistance-associated mutations are not commonly observed in newly-infected subjects is not because they impact on the ability of HIV to be transmitted but rather because they may quickly revert to wild-type in the absence of drug pressure and then be rapidly overgrown by wild-type variants.

Published: 11 May 2010

doi:10.1186/1742-4690-7-S1-121

Cite this article as: Wainberg et al:: Use of new resistance markers to predict virologic response to antiretrovirals. Retrovirology 2010

7(Suppl 1):121.

\section{Submit your next manuscript to BioMed Central and take full advantage of: \\ - Convenient online submission \\ - Thorough peer review \\ - No space constraints or color figure charges \\ - Immediate publication on acceptance \\ - Inclusion in PubMed, CAS, Scopus and Google Scholar \\ - Research which is freely available for redistribution \\ Submit your manuscript at www.biomedcentral.com/submit}

